\title{
FW 円筒の衝撃横圧縮荷重下に护る破壊挙動に関する研究
}

$$
\begin{aligned}
& \text { 平 井 恒 } \text { 夫 }^{*} \text { 横 山 敦 } \text { 士** }^{* *} \\
& \text { 村 田 泰 彦***武 藤 義 弘**** }
\end{aligned}
$$

\section{Fracture Behavior under Impact Lateral Compression in Filament-Wound Composites}

by

\author{
Tsuneo Hirai*, Atsushi Yokoyama**, Yasuhiko Murata*** \\ and Yoshihiro MuTOH****
}

When a helical-wound composite cylinder is subjected to lateral compression load, delamination ocurres in the interlamina. This delamination causes a remarkable decrease in strength.

In this paper the behavior of macroscopic failure of helical-wound composite cylinder under impact lateral compression load is observed experimentally and the elemental property is made clear. From the numerical analysis, it is made clear that stress wave propagation induces macroscopic fracture.

The following are the main results.

(1) The fracture behavior of helical-wound composite cylinder under impact lateral compression load is affected by the deformation velocity and the winding-angle of filament.

(2) The impact absorbed energy of helical-wound composite cylinder under impact lateral compression load increases with increasing deformation velocity, and this effect becomes remarkable when the winding-angle was large.

(3) The fracture of helical-wound composite cylinder ocurres in fiber boudle and interlamina. In paticular, interlamina fracture causes a remarkable decrease in strength, because the speed of stress wave propagation is affected by the different mechanical impedance of the fiber boudle-layer and the resin-layer.

キー・ワード : 衝撃横圧縮荷重, 層間はく離，メカニカルインピーダンス，応力波伝ぱ

\section{1 緒言}

ヘリカル巻き FW 円筒は, その円筒軸と垂直な方 向の負荷（横圧縮負荷）により内部界面に执いて層間 はく離を生ずる.この層間はく離は材料の強度低下を 招くだけでなく，その機能を損なら大きな原因となり らる. 近年 $\mathrm{FW}$ 材が航空機の機体・自動車のプロペ ラシャフトなど高速度で移動する物体に応用され，適 用範囲が広くなりつつある。そのため衝撃負荷下での FW 材の破壊挙動を明らかにする必要性が生じてきた。

すでに，著者らは FW 円筒に対して準静的な横圧 縮荷重を負荷した場合の微視的および巨視的な破壊挙 動を実験により観察し，これらの破壊に及ぼす異方性 の影響を数值解析により検討してきた. そこで，本報 では FW 円筒に対して衝撃横圧縮荷重を負荷した場 合の材料内部の破壊挙動を観察し，その基本的特性を
明らかにした.さらに, FW 円筒の破壊発生機構を明 確にするために, 衝撃初期の応力波伝ば機構を数值解 析により求め検討した.

\section{2 供試材料および実験方法}

本研究で用いた試料は，ガラス 繊維一エポキシ樹脂 ヘリカル巻き FW 円筒である. その試料形状を Fig.

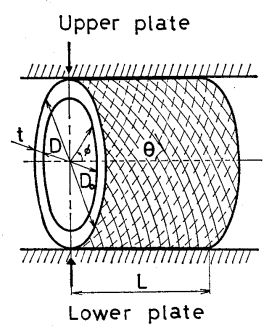

Fig. 1. Shape of specimen.

\footnotetext{
$† \quad$ 原稿受理 昭和60年 7 月15日 Received July 15, 1985

* 正会 員 同志社大学工学部 京都市上京区鳥丸今出川, Department of Mechanical Engineering, Doshisha University, Karasumaimadegawa, Kamigyo-ku, Kyoto

** 正会 員 大阪府立工業技術研究所 大阪市西区江之島, Osaka Prefectual Industrial Research Institute, Enokojima, Nishi-ku, Osaka

*** 同志社大学大学院 京都市上京区鳥丸今出川, Graduate Student, Doshisha University, Karasuma-imadegawa, Kamigyo-ku, Kyoto

**** 学生会員 同志社大学大学院 京都市上京区烏丸今出川, Graduate Student, Doshisha University, Karasuma-imadegawa, Kamigyo-ku, Kyoto
} 
Table I. Dimension of specimen.

\begin{tabular}{c|c|c|c|c|c|c}
\hline $\begin{array}{c}\text { Speci- } \\
\text { men }\end{array}$ & $\begin{array}{c}\text { Ply } \\
\text { angle } \\
\theta(\text { deg. })\end{array}$ & $\begin{array}{c}\text { Outer } \\
\text { dia- } \\
\text { meter } \\
D(\mathrm{~mm})\end{array}$ & $\begin{array}{c}\text { Inner } \\
\text { dia- } \\
\text { meter } \\
D_{0}(\mathrm{~mm})\end{array}$ & $\begin{array}{c}\text { Thick- } \\
\text { ness } \\
t(\mathrm{~mm})\end{array}$ & $\begin{array}{c}\text { Width } \\
L(\mathrm{~mm})\end{array}$ & $\begin{array}{c}\text { Ratio of } \\
D_{0} \text { to } D \\
D_{0} / D\end{array}$ \\
\hline A & 76.0 & 38.0 & 30.0 & 4.0 & 15.0 & 0.79 \\
B & 47.4 & 38.0 & 30.0 & 4.0 & 15.0 & 0.79 \\
\hline
\end{tabular}

1 にとの主要寸法を Table I に示す。な括，試料幅 と外径内径比は JIS K6911 に準拠したものであり， 試料 $\mathrm{A}$ と B は巻き角度のみが異なっているものである. 衝撃横圧縮試験に用いた試験機は, 二度打ち防止装 置が設けられているダイナタップ・ドロップウェイト ・インパクトシステム (Model 8000b) であり, 本研 究の目的に合せて荷重検出部を Fig. 2 に示すように 計装化したものである. 荷重検出方法は, ガイドポス トに沿って落下する重錘側部のフラッグがレーザ光を 遮り，フォトトランジスタの電圧変化によりトリガを 発生させ，すべての装置の同期を行うものである. 衝

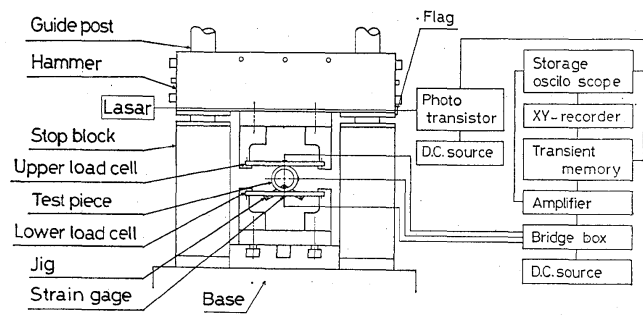

Fig. 2. Schematic diagram of load detector.

撃荷重は, 打撃側あるいは支持側のロードセルに貼付 されたひずみゲージの抵抗変化をブリッジ回路と直流 増幅器を通してデジタル・ストレージ・オシロスコー プに一たん記憶させ，その後 XY 記録機にその波形 を出力させた。 な就，ロードセルに和ける出力電圧と 静的荷重との間には線形な較正関係が得られている.

また，衝撃横圧縮下の FW 円筒の破壊状態を知るた めに、トリガによって同期する遅延装置とストロボ発 光装置を用いて試料端面の写真撮影を行った.

実験は衝撃速度を2.42・3.65・4.26(m/s) の 3 段 階に変化させて行った。

\section{3 実験結果および考察}

\section{$3 \cdot 1$ 衝擊横圧縮を受ける $\mathrm{FW}$ 円筒の破壊様相}

巻き角度 $76.0^{\circ}$ の試料 A V対して衝撃速度 $2.42(\mathrm{~m} /$ s）で衝撃横圧縮負荷を加えた場合の衝撃荷重之試料 上部の変位の関係を Fig. 3 に示す. 図中に执いて, 実線は打撃側ロードセル，破線は支持側ロードセルに よって測定されたものである. 打撃側の荷重は比較的 緩やかに立ち上り, 変位量 $1.0(\mathrm{~mm})$ 付近で剛性の低 下が見られ, 変位量 $2.3(\mathrm{~mm})$ 付近で衝撃荷重の急激 な低下現象が起る. その後, 衝撃荷重は振幅の大きい

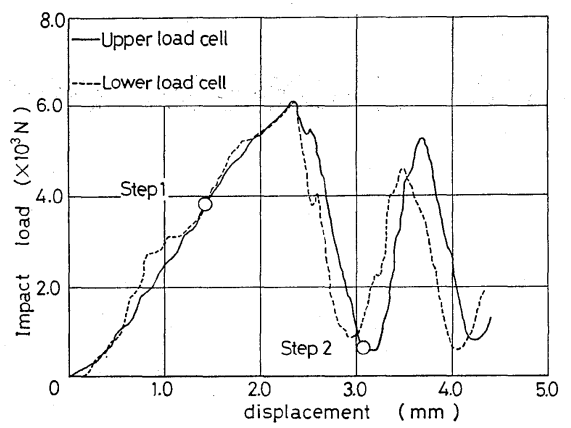

Fig. 3. Relation between impact load and displacement of specimen A $(V=2.42 \mathrm{~m} / \mathrm{sec}$. $)$.

規則的な振動を繰り返しながら減少し最終破壊に至る. 支持側は打撃側に対して約 $65(\mu \mathrm{s})$ の遅れが見られ， 打撃側より急激な立ら上りを示すがほぼ打撃側の衝撃 荷重一変位曲線と同様の傾向を示す.

巻き角度 $47.4^{\circ}$ の試料 B に対して衝撃速度 2.42 $(\mathrm{m} / \mathrm{s})$ で衝撃横圧縮負荷を加えた場合の衝撃荷重と変 位の関係を Fig. 4 に示す. 打撃側・支持側とも試料 A とほぼ同様の変位量に打いて剛性低下と荷重の急激 な低下が見られるが，試料Bに和汗る衝撃荷重一変位 曲線は試料 $\mathrm{A} て ゙$ 見られたような急激な変化はなく，比 較的緩やかな増減を示す. また，支持側の打撃側に対 する立ち上りの遅れは約 $90(\mu \mathrm{s})$ である.

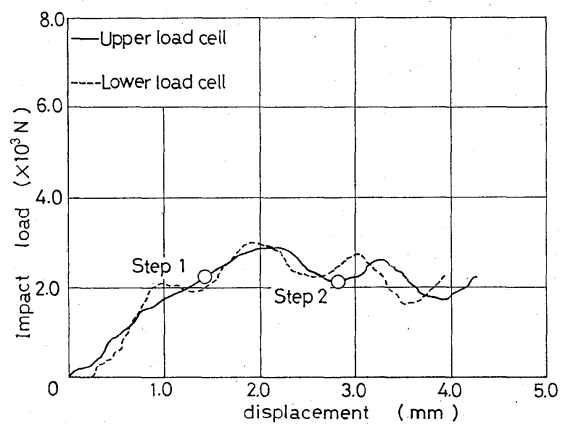

Fig. 4. Relation between impact load and displacement of specimen B $(V=2.42 \mathrm{~m} / \mathrm{sec}$. $)$.

ここで FW 円筒の破壞の様相を調べるために， 衝 撃荷重一変位曲線に和ける剛性の低下する点 (step 1) と一回目の急激な荷重の低下を示す点 (step 2) にお いて試料端面の写真撮影を行った.

Fig. 5 に衝撃速度 $2.42(\mathrm{~m} / \mathrm{s})$ に対する試料Aの写 真とスケッチ図を示す. step 1 では試料下部が偏平 しているが，この図からは試料内部の破壊状況を明確 に観察することはできない. step 2.では試料斜め上 部之下部の内側から約 3 分の 1 の位置に内部界面方向 に沿って層間はく離が生 じているのが確認できる. Fig. 6 に和ける試料端面の写真とスケッチ図は試料 B の衝撃速度 $2.42(\mathrm{~m} / \mathrm{s})$ の場合である. step 1 では試 

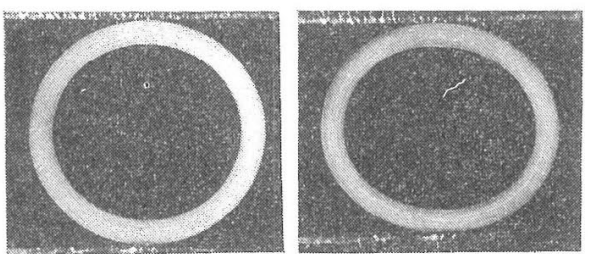

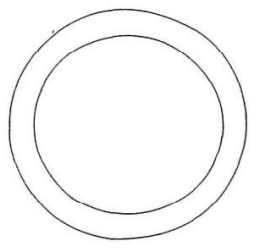

Step 1

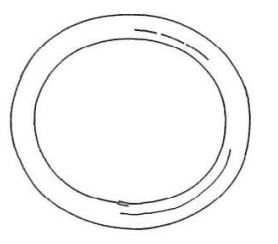

Step 2
Fig. 5. Aspect of delamination growth on specimen A $(V=2.42 \mathrm{~m} / \mathrm{sec}$. $)$.
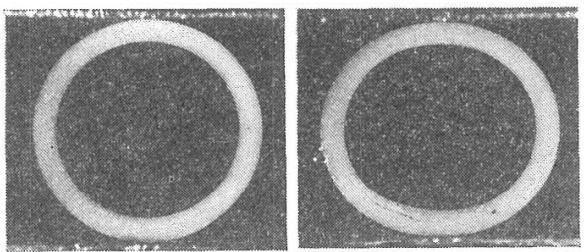

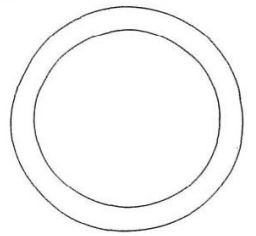

Step 1

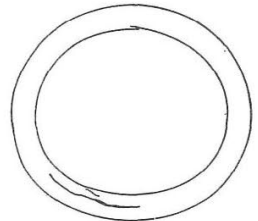

Step 2
Fig. 6. Aspect of delamination growth on specimen B $(V=2.42 \mathrm{~m} / \mathrm{sec}$. $)$.

料 $\mathrm{A}$ と同様に試料下部が偏平しているのみで等る。乙 かし, step 2 では試料下部内側から約 3 分の 1 の位 置の内部界面方向に和战る層間はく離に加兄て, 試料 A とは異なった瀻維束の破壤が見られる。

\section{$3 \cdot 2$ 破壞椂相に及ばす变形速度の影響}

衝撃速度员 $2.42 \cdot 3.65 \cdot 4.26(\mathrm{~m} / \mathrm{s})$ の 3 段階に変 化させて試料 $\mathrm{A}$ と試料 B V衝撃横圧縮負荷を加光た。

Fig. 7 に㿉間はく離による衝撃荷重の急激な低下現 象が起るまでの試料 $\mathrm{A}$ の衝撃荷重と変位の関係を各衝 撃速度について示す。衝撃速度 $3.65 ・ 4.26(\mathrm{~m} / \mathrm{s})$ の 衝撃何重一変位曲線は, 衝撃速度 $2.42(\mathrm{~m} / \mathrm{s})$ のbのと 同様の傾向省示し，荷重の急激な低下現象が起る変位 量に就いて衝撃速度の違いによる変化は見られない。 しかし, 衝撃速度の增加に伴い最大荷重む增加する傾 向に㐫る.Fig. 8 に試料B の衝撃荷重と変位の関係を 示す。試料 $\mathrm{B}$ に扔いて子試料 $\mathrm{A}$ と同栐に衝撃速度の增 加に伴って最大荷重が増加する。 乙かし, 衝撃荷重一 変位曲線は試料 Aとは異なり，衝撃速度によって最大

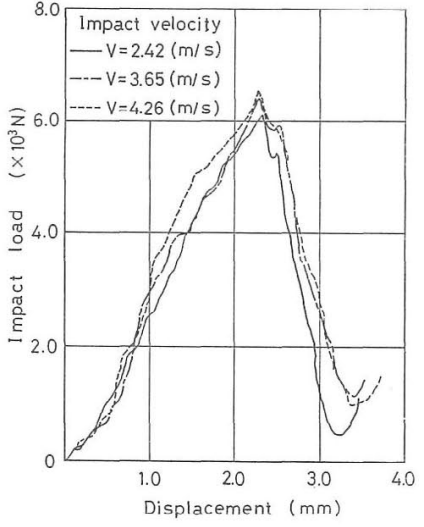

Fig. 7. Relation between impact load and displacement of specimen A.

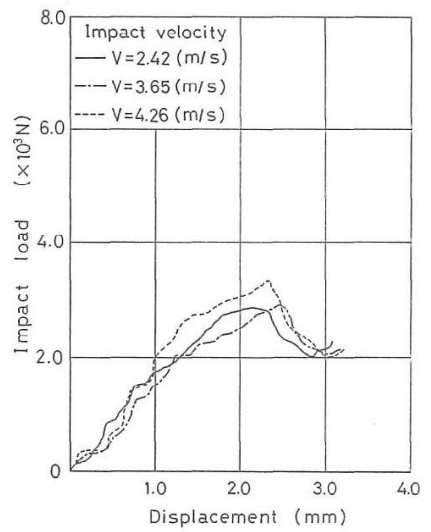

Fig. 8. Relation between impact load and displacement of specimen B.

荷重の発生する变位量に差が見られる。また，その曲

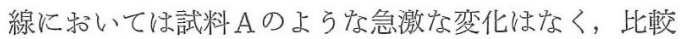
的緩やかな曲線的変化を示吉。

つぎに, 衝撃速度 $2.42 \cdot 3.65(\mathrm{~m} / \mathrm{s})$ について破壤 の様相が顕著に見られる step 2 の試料端面の写真に
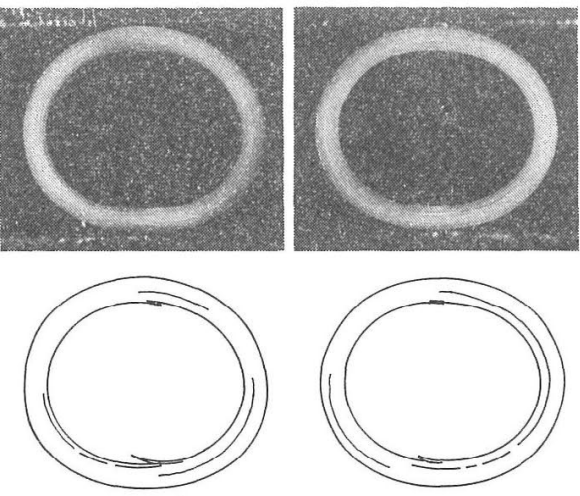

$V=3.65(\mathrm{~m} / \mathrm{sec}$.

$V=4.26(\mathrm{~m} / \mathrm{sec}$.

Fig. 9. State of delamination in Step 2 (specimen A). 

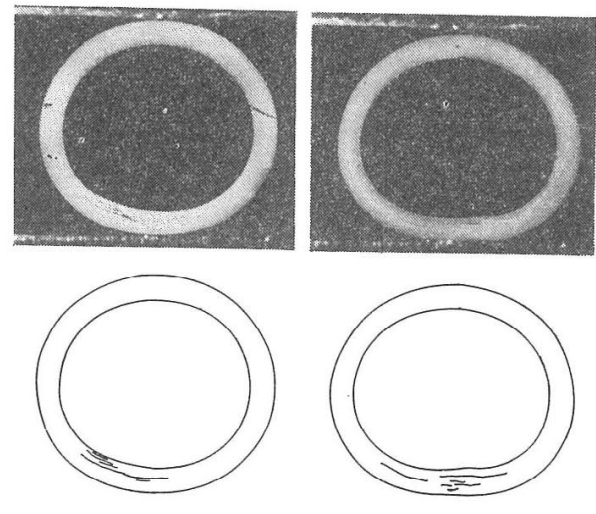

$V=3.65(\mathrm{~m} / \mathrm{sec}$.)

$V=4.26(\mathrm{~m} / \mathrm{sec})$

Fig. 10. State of delamination in Step 2 (specimen B).

\section{ついて検討する.}

Fig. 9 に試料Aの試料端面の写真とスケッチ図を示 す. 試料 A では, 衝撃速度の增加に伴い内部界面に沿 って層間はく離が拡大寸る。Fig. 10 に試料Bの場合 を示す。試料Bでは内部界面に特いて層間はく離が生 じるが，衝撃速度の増加による变化はほとんど見られ ず繊維束内に発生する破猿が増大する傾向にある。

このように，試料 $\mathrm{A} か ゙$ 層間はく離による樹脂層のみ の破壞で荷重低下が発生するのに対し, 試料Bでは層 間はく離に加光繊維束内の破踾が発生し 2 種類の破壞 が組み合さった複雑な破壤様相を示す。この複雑な破 壞が発生するために，試料Bでは最大荷重を示す変位 量が異なり衝撃荷重一変位曲線は比軦的緩やかな曲線 的変化を示方.

\section{$3 \cdot 3$ 吸收エネルギに及ばす速度の影響}

衝撃荷重一娈位曲線に和ける急激な荷重の低下現象 が見られるのは層間はく離により試料内部に蓄積され たエネルギが内部界面で開ロエネルギとして費やされ るためと予測される。そこで，衝撃荷重が急激に低下 するまでの吸収エネルギについて検討した。吸収エネ ルギは次式により算出しだ。

$$
E_{a}=\int_{0}^{T} v_{u} p_{u} d t-\int_{0}^{T} v_{l} p_{l} d t
$$

ここで， $E_{a}$ は吸収エネルギ $(\mathrm{N} \cdot \mathrm{m}), v$ はロードセル の変形速度 $(\mathrm{m} / \mathrm{s}), \quad p$ は椧出された荷重 $(N)$, 添光 字ル・lはそれぞれ打撃側・支持側を示し，時刻 $T$ は ひずみ量 $0.4 \cdot 0.6 \cdot 0.8(\%)$ および破壞（step 2) に 相当する時間とした，な新，吸收エネルギを算出する 際，層間はく離の発生する step 2 までの初期を検討 したため，変形速度 は一定とみなした。 Fig.11に 試料 $\mathrm{A}$ の吸収エネルギと変形速度の関係を示示. 吸収

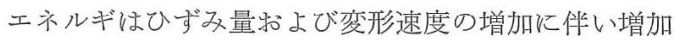
する.とくに衝撃的な負荷を受ける範囲内では, 吸収

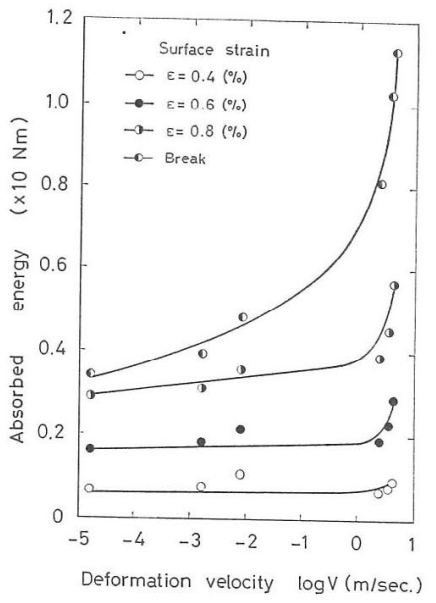

Fig. 11. Relation between absorbed energy and deformation velocity on specimen $\mathrm{A}$.

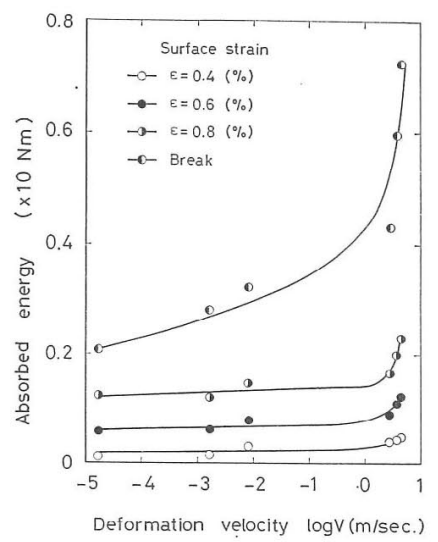

Fig. 12. Relation between absorbed energy and deformation velocity on specimen $B$.

エネルギの 増加の割合が非常に大きくなる. Fig. 12 に試料 Bの吸収エネルギと変形速度の関係を示す。試 料Bでは試料 A と同じ傾向を示すが，吸収エネルギが 小さいことがわかる。

以上の実験結果より, 衝撃横圧縮負荷を受ける FW 円筒に和いては巻き角度和よび衝撃速度が大きくなる ほど，最大荷重叔よび吸収エネルギに対して大きな影 響を及ぼす。きた，FW 円筒の衝撃横圧縮負荷下の剛 性低下の原因は実験では明確にすることができなかっ た、しかし，その後層間はく離が試料下部内側から約 3 分の 1 の位置で発生し内部界面方向に沿って桩大す るため，荷重の急激な低下が起ることが確認できた。

\section{4 数值解析による応力波伝ぱ機構の解明}

実験に和いて層間と䋐維束の 2 種類の破壞を確認す ることができ，とくに FW 円筒の強度に影響を及ぼ す原因は層間はく離であることが認められた。本章で は，FW 円筒の巨視的な破壞発生機構をよりよく明ら かにするために衝撃初期の応力波の伝ぱ状況を数值解 
析により求め, 応力波の伝ぱが巨視破壊の発生に与兄 る影響について検討した.

\section{$4 \cdot 1$ 解析モデル}

すでに著者らは静的横圧縮荷重を受ける FW 円筒 には巻き角度の相違による異方性括よび絨維束と樹脂 との界面での変位の不連続性を考慮したモデルを提案 し，その有効性を認めてきた。 しかし，衝撃負荷を受 ける場合, 繊維束層と樹脂層のメカニカルインピーダ ンスの相違が衝撃負荷初期の応力波伝ぱに大きな影響 を与えると考えられ，巨視的な観点からの繊維束層の 存在を明確に考慮したモデルを用いた。 そこで，材料 定数の異なるプライグループを同心円上に重ねた。 こ れにより FW 円筒に扣いて繊維束層と樹脂層が交互 に積層されているものとし，極座標系つまり半径方向 に対して異方性の效果が与えられたことになり，これ を混合モデルとした。

用いた要素は六面体八節点要素であり，ここでは $Z$ 方向の変位をすべて拘束し二次元化を行った. Fig. 13 に要素分割図を示す. 境界条件は $\mathrm{A} \sim \mathrm{B} ・ \mathrm{C} \sim \mathrm{D}$ の $X$ 方向変位およびDの $Y$ 方向変位を拘束し，円筒と重錘 および円筒と固定面との間の接触を考慮した，要素分 割は半径方向について12のプライグループに分割し， 図中黒塗りのプライグループは樹脂層を，他のプライ

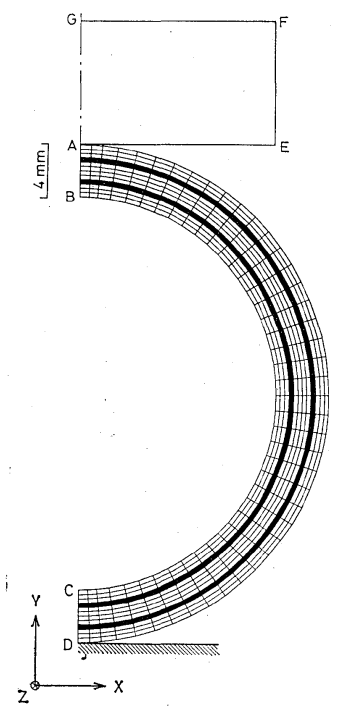

Fig. 13. Model used in impact analysis.
グループは絾維束層とした．なお，解析モデルの構成 関係は繊維束層, 樹脂層とも等方性弾塑性体を用いた. これらの材料定数を Table II に示す. また静的な負 荷を受ける FW 円筒の数值解析結果によると 繊維束 層と樹脂層との界面に働くせん断応力が破壞発生に対 して大きな影響を及ぼすことが明らかとなっているた め，ここでは最大せん断応力を用いて破壊発生につい て検討した.

\section{$4 \cdot 2$ 数値解析結果と考察}

混合モデルに対する衝撃荷重負荷後 $20(\mu \mathrm{s})$ の最大 せん断応力分布を Fig. 14 に示す. 混合モデルでは, 衝撃荷重を負荷した点の繊維束層で高い応力值を示し, 応力波は試料内側 - 外側とも繊維束層で速く進行乙試 料斜め下部まで達している. しかし樹脂層では試料斜 め上部にとどまり繊維束層に対して遅れを生じている. また，繊維束層と樹脂層の応力波はそれぞれ $20(\mu \mathrm{s})$ ・30( $\mu$ s) で試料下部に達していた.

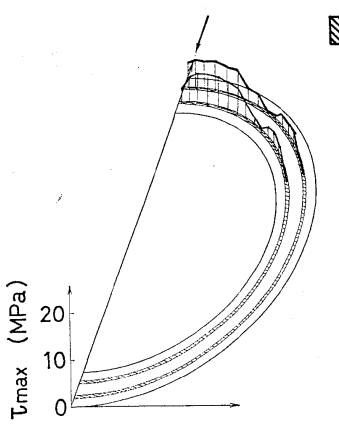

Resin layer

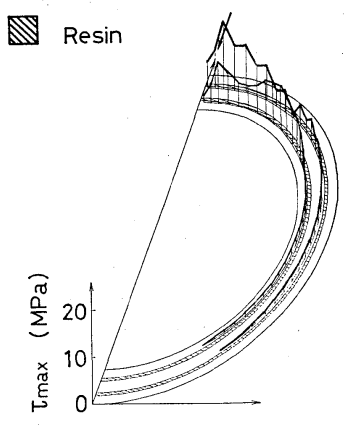

Fiber bundle layer
Fig. 14. Diagram of maximum shearing stress distribution (Time $=20 \mu \mathrm{s}$ : Mixed model).

混合モデルに対する衝撃荷重負荷後 $100(\mu \mathrm{s})$ の最大 せ九断応力分布を Fig. 15 に示す. 負荷後 $100(\mu \mathrm{s})$ で は, さらに応力波は円周方向に進久試料下部で応力波 の反射が見られる．また，円周方向すべての領域で高 い応力值を示しとくに試料側部と下部の内側繊維束層 で高い值を示して拈り, 繊維束層と樹脂層との間に応 力値の差が生じている.

一方，等方性モデルに対する衝撃荷重負荷後50( $\mathrm{s}$ ) の最大せん断応力分布を Fig. 16 に示す. 等方性モデ ルでは, 混合モデルと同様に衝撃点直下で高い応力值

Table II. Material constants.

\begin{tabular}{|c|c|c|c|c|c|c|c|}
\hline & & $\begin{array}{l}\text { Young's } \\
\text { modulus } \\
E_{x}(\mathrm{GPa})\end{array}$ & $\begin{array}{l}\text { Young's } \\
\text { modulus } \\
E_{y}(\mathrm{GPa})\end{array}$ & $\begin{array}{l}\text { Shearing } \\
\text { modulus } \\
G_{x y}(\mathrm{GPa})\end{array}$ & $\begin{array}{c}\text { Poisson's } \\
\text { ratio } \\
V_{x}\end{array}$ & $\begin{array}{c}\text { Yielding } \\
\text { stress } \\
\sigma_{y}(\mathrm{MPa})\end{array}$ & $\begin{array}{c}\text { Hardening } \\
\text { ratio } \\
H(\mathrm{GPa})\end{array}$ \\
\hline \multirow{2}{*}{ Mixed model } & Reinforced layer & 33.0 & 33.0 & 13.2 & 0.25 & 24.5 & 26.5 \\
\hline & Resin & 2.94 & 2.94 & 1.08 & 0.36 & 9.80 & 0.59 \\
\hline \multicolumn{2}{|c|}{ Homogeneous isotropic model } & 13.9 & 13.9 & 6.01 & 0.16 & 10.8 & 5.45 \\
\hline
\end{tabular}




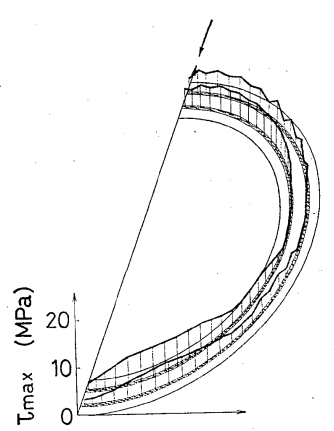

Resin layer

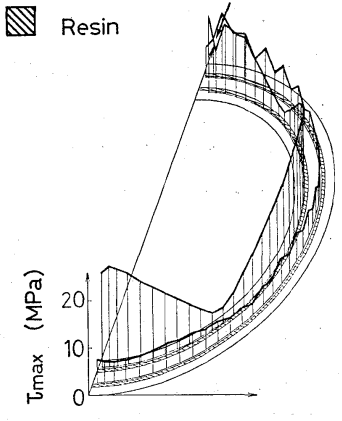

Fiber bundle layer
Fig. 15. Diagram of maximum shearing stress distribution (Time $=100 \mu \mathrm{s}$ : Mixed model).

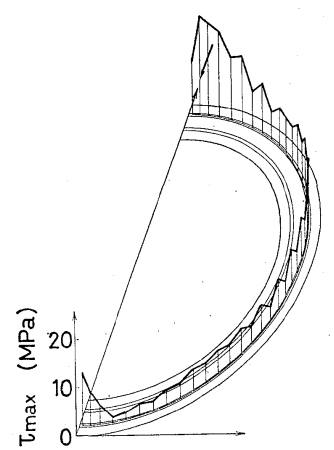

Outer layer

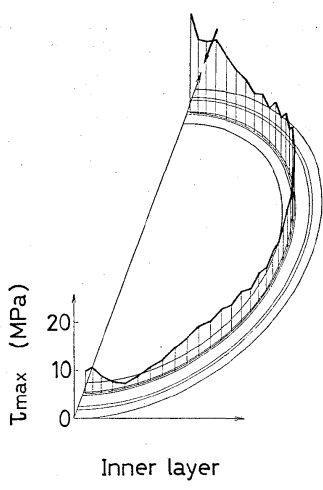

Inner layer
Fig. 16. Diagram of maximum shearing stress distribution (Isotropic model).

をとるが，応力波は試料内側・外側とも同じような進 展を示す。 をた，応力波は試料下部认達して和り, 混 合モデルで見られたような試料内側と外側とでの応力 值の差は見られなかった.さらに試料下部対称面付近 に括いて応力波の反射が起っているのが確認できる.

つぎに，混合モデルと等方性モデルの塑性ひずみが 生じた領域より破壞発生位置を検討する。

最大せん断応力分布図より応力波の反射が見られ， 樹脂層と繊維束層との応力値の差が大きくなる負荷後 $100(\mu \mathrm{S})$ の混合モデルと等方性モデルの試料内に発生 する塑性域の分布を Fig. 17 に示す，混合モデル，等 方性モデルとも衝撃点直下で塑性域が多く発生してい る.また，試料内側表層は全域が塑性域となっている. 等方性モデルでは，試料側部表層に多くの塑性域が生 じているのに対して，混合モデルでは試料内側の繊維 束層と樹脂層に塑性域が生じている.

以上の結果より, 混合モデルに执いては, 試料下部 内側から 3 分の 1 の位置で応力値が高くなり塑性域が 生じる。これは実験で見られたは層間く離発生位置と 良い一致を示している. このことから FW 円筒に衝
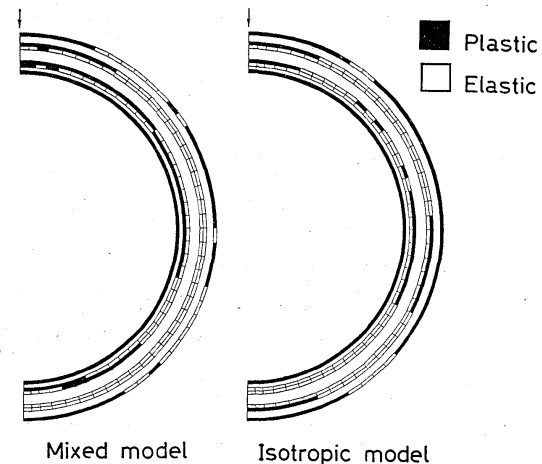

Fig. 17. State of plastic strain (Time $=100 \mu \mathrm{s}$ ).

撃横圧縮荷重が負荷されると試料下部内側から約 3 分 の 1 の位置で剛性低下の原因となる微視破壊が発生し, その後応力波の反射の繰返しによりその位置での応力 值が高まり巨視破壊に至ると推測される。

\section{5 結言}

巻き角度の異なる 2 種類 のベリカル巻き $\mathrm{FW}$ 円筒 に対して衝撃横圧縮負荷を加え, その結果を検討し FW 円筒の破壊挙動を明らかにした. さらに, 実験に 括いて解明することが困難な衝撃初期の応力波伝ぱ機 構を明らかにした，その結果を次に示す。

（1）衝撃横圧縮負荷を受ける FW 円筒の破壊挙動 は試料の巻き角度と变形速度の影響を受ける. 巻き角 度の大きい FW 円筒では変形速度の增加に伴い層間 はく離が内部界面方向に拡大寸る. それに対し巻き角 度の小さい FW 円简では層間はく離と緎維束内の破 壊が起りその破壊様相は変形速度㳘影響される.

（2）衝撃横圧縮負荷を受ける FW 円筒の吸収エネ ルギは変形速度の增加に従って大きくなり，その影響 は巻き角度が大きい場合ほど顕著である。

（3）FW 円筒には繊維束之層間の破壊が考兄られ， とくに FW 円筒の強度低下を招く破壞は層間はく離 であり, 数值解析より得られたはく離発生位置と一致 した。この層間の破壊は絨維束層と樹脂層のメカニカ ルインピーダンスの相違が応力波伝ぱ速度に影響を与 壳, 層間でのせん断応力值の差を招くことにより発生 することが明らかとなった。

（昭和60年 3 月20日 第14回 FRP シンポジウムにて講演）

\section{参 考 文 献}

1）平井恒夫, 片山伝生, 濱田泰以, 村田泰彦, 材料, $\mathbf{3 4}$, 377 (1985).

2) JIS K6911.

3) F. A. Myers, 37th Annual Conference, Reinforced Plastic/Composites Institute, 1-C, 1 (1982). 